\title{
D Vitamininin Çeșitli Hastalıklardaki Nadir Kullanım Alanları
}

\author{
The Area of Usage of the Vitamin D in Different Diseases and Unknown Benefits
}

Aysun Genç1', Duygu Gülmez Sevim², Aslı Tok Özen³, Gülden Yılmaz ${ }^{4}$

Ankara Üniversitesi Haymana Meslek Yüksekokulu, Terapi ve Rehabilitasyon Bolumü, Fizyoterapi Programı, Ankara, Türkiye 2 Erciyes Üniversitesi Tıp Fakültesi, Göz Hastalıkları Anabilim Dalı, Kayseri, Türkiye

Ankara Üniversitesi Haymana Meslek Yüksekokulu, Sağlık ve Bakım Hizmetleri Bölümü, Yaş̧ı Bakımı Programı, Ankara, Türkiye

政 Mikrobiyoloji Anabilim Dall, Ankara, Türkiye

D vitamini, serum kalsiyum ve fosfor düzeylerini, emilim ve metabolizma üzerinden etkileyerek düzenler. D vitamini reseptörlerinin vücudun birçok doku ve hücresinde tespit edilmesiyle, klasik olmayan etkileri araștırılmaya bașlanmıștır. Hiperkalsemik etkilerinin ortaya çıkmadığı dozlarda verilen vitamin ile diabetes mellitus, multipl skleroz, amyotrofik lateral skleroz, metabolik sendrom gibi birçok hastalıkta elde edilen umut veren sonuçlar mevcuttur. Bununla beraber hangi hastalara ve risk faktörü olanlara hangi dozlarda önerileceği konusu belirsizdir. Bu derlememizde rutin kullanım alanları dıșında $D$ vitamini uygulamaları ve elde edilen sonuçları ayrı ayrı ele alınarak derlenmiștir.

Anahtar Sözcükler: D Vitamini, Kanser, Göz Hastalıkları, Nörolojik hastalıklar, Infeksiyon Hastalıkları

Vitamin $D$ regulates the serum calcium and phosphorus levels by effecting absorption and metabolism of these minerals. Since determining the vitamin $D$ reseptors are expressed in many tissue and cells, non-clasical effects of vitamin $D$ was begun to be investigated. Promising results with non-hypercalcemic doses of vitamin $D$ are available in many diseases such as diabetes mellitus, multiple sclerosis, amyotrophic lateral sclerosis and metabolic syndrome. Additionally the patient selection, risk factors and doses of the vitamin are uncertain. We aimed to review non-routine usages of vitamin D and obtained results.

\section{Key Words: Vitamin D, Cancer, Eye Diseases, Neurologic Diseases, Infection Disease}

D vitamini, mineral dengesinde görevli bir bileșiktir. Serum kalsiyum ve fosfor düzeylerini, bu minerallerin metabolizma ve emilimini etkileyerek düzenler. Hedef organları böbrekler, ince barsaklar ile kemiktir ve bu organlardaki etkiler aktif formu olan kalsitriol tarafindan ortaya konulur. D vitamini eksikliğinde klasik olarak çocuklarda rikets hastalığı, erişkinlerde ise osteoporoz izlenir (1).

Klasik olarak D vitamini eksikliği, güneş 1şınlarına zayıf maruziyet, malabsorbsiyon, fenitoin ve fenobarbital gibi çeşitli medikasyonlara bağlı artmış katabolizma ve infantlarda D vitamininden fakir anne sütü ile beslenme sonucunda oluşmaktadır. Klinik genel olarak sessiz olmakla birlikte, erişkinlerde kronik kas ağriları ile belirti verebilir. D vitamini yetmezliğinin tedavisi ve tedavi süresi hastanın yaşına, altta yatan nedene göre değişkenlik gösterir. (2,3).
Son zamanlarda D vitamininin klasik olmayan etkilerinin araştırıldığ 1 yayınlar ardı ardına bildirilmektedir. Bu çalışmalar sayesinde $\mathrm{D}$ vitaminin aktif formu olan kolekalsiferol (vitamin D3) reseptörü insan vücudunun birçok doku ve hücresinde tespit edilmiştir. Kanser, otoimmun hastalıklar, diabetes mellitus (DM) gibi bazı hastalıklarla D vitamini arasındaki ilișkiler hakkında birçok hipotez ortaya konulmuştur (2). Ayrica doğuştan ve kazanılmıș immünitedeki etkileri çal1şılmıştır. Bu çalışmalarda genel olarak kalsitriolün gen düzeyinde aktivite artışına neden olduğu öne sürülmüştür (4). Aynı zamanda vitamin D eksikliği ile multipl skleroz (MS), ateroskleroz ve inflamatuar barsak hastalığ1 gelişimi arasındaki ilişki ortaya konulmuştur (2). Biz bu yazımızda D vitamininin rutin kullanım alanları dişındaki uygulamalarını ve sonuçlarını ayrı ayrı ele alarak derlemeyi amaçladık. 


\section{Vasküler hastalıklar ve Diabetes mellitus}

Osteoporoz ile karotid arter aterosklerozu arası ilişki olduğu ve kardiyovasküler hastalıklarda $25-(\mathrm{OH})$ D vitamini seviyesinin genel olarak düşük olduğu bilinmektedir. $\mathrm{D}$ vitamini ve vasküler etkilerinin incelendiği literatürde çeşitli çalışmalar mevcuttur. Günlük oral olarak yüksek doz D vitamini verilen ratlarda serum lipidleri, CRP ve adezyon moleküllerinin anlamlı olarak azaldığı gösterilmiştir. Ayrıca aortik halkalar D vitamini ile inkübe edildiğinde nitrik oksit anlamlı olarak artmış, malondialdehit ise anlamlı olarak azalmıştır (5). D vitaminine benzer olarak kalsitriol tedavisi $(1 \mu \mathrm{g} / \mathrm{kg})$ intakt renal fonksiyonu olan ratların aort media tabakası içinde vasküler kalsifikasyonu zaman-bağımlı olarak indükler. Kalsitriol çekilmesinden sonra vasküler kalsifikasyonlar hızlı olarak geriler ve 9 hafta içinde \% 75'e varan oranlarda aortta kalsiyum ve fosfor azalır (6). Üremik ratlarda ise non-hiperkalsemik dozlarda $(0,25$ $\mathrm{mg} / \mathrm{kg} /$ gün) oral kalsitriol tedavisi dahi, intima ve media tabakalarının tutulduğu difüz aortik kalsifikasyonla sonuçlanır. Ek olarak deneklerde sol ventriküler hipertrofi görülür (7). Bu iki çalışmadan da anlaşılacağı üzere D vitamini tedavisinde böbrek fonksiyonları mutlak göz önünden bulundurulmalıdır.

Tip 1 DM olan hastalarda morbidite ve mortalitenin ana nedeni vasküler komplikasyonlar olup ana patolojik mekanizma aterosklerozdur (8). Tip 1 DM'de D vitamini eksikliği glukoz intoleransinı ve insulin sekresyonunda değişiklikleri predispoze eder. Moleküler düzeyde pankreatik $\beta$ hücre disfonksiyonu ile sistemik inflamasyonda bozukluk vardır (9). Diabetik ratlar üzerinde bu konuyu araştırmak için yapılan bir çalışmada, yüksek doz aktif D vitamini patolojik aortik değişiklikleri ve kollajen depolanmasını azalttığ1 gösterilmiştir. Yine bu çalışmada DM nedeniyle artan Toll Like Receptor 4 (TLR4), Myeloid differentiation primary response gene 88 (MyD88), Nuclear Factor kappa B $(\mathrm{NF}-x \beta)$ seviyelerinde azalma tespit edilmiştir (8).
Deoksiribo Nükleik Asit (DNA) mikrodizin teknoloji kullanılarak kalsitriolün ve $\mathrm{D}$ vitamini analoğu parikalsitriolün 100 'den fazla gende upregulasyon ve 50'den fazla gende ise bask1lanma yaptığ1 gösterilmiştir (10). Endotelyal hücreler 1- $\alpha$ hidroksilaz aktivitesi gösterebilir ve endotelyal hücre aktivasyonunun parakrin/intakrin düzenleyici etkisi olan kalsittriol üretir. Endotel hücrelerinde kalsitriol antijen ile indüklenmiş, sitokin aracilı endotel hücre aktivasyonunu genel olarak ve özellikle TNF- $\alpha$ ile indüklenmiş adezyon moleküllerini inhibe eder. $\mathrm{Bu}$ etkilerin fizyolojik olarak önemi olabilir çünkü adezyon moleküllerinin ateroskleroz erken evrelerinde etkili olduğu hakkında kanıtlar mevcuttur (11).

Arteriyel kalsifikasyona ek olarak D vitamininin intimal hiperplazi üzerine etkileride çalışılmıştır. Ratlarda balon ile hasarlanmış arterler üzerinde yap1lan çalışmada D vitamini ile tedavi edilen deneklerde anlamlı olarak intimal kalınlık fazla bulunmuştur (12).

DM'nin patogenezinde ve hastaliktan korunmada D vitaminin rolü vardır. Hayvan modellerinde aktif D vitamini, T hücre diferansiasyonunun düzenlenmesi, dendritik hücre aktivasyonu ve sitokin sekresyonu arttırmas1 ile tip $1 \mathrm{DM}$ için koruyucudur (13). Aktif D vitamini aynı zamanda $\beta$ hücre fonksiyonunu etkiler. Wang ve ark.(14) tarafindan diabetik farelerde erken hayatta uygulanan D vitamini desteği streptozosin ile indüklenmiş açlık kan glukozunu ve, DM insidansını azaltabildiği ile sonuçlanmıştır. Yine bu çalışmada insülin içeriğini up-regüle ettiği ve pankreas adacık hücre hasarını azaltabildiği sonucunada varılmıştır. Ayrıca başka bir çalışmada da yaşam boyu yüksek doz D vitamini desteği alan farelerde güvenli olarak DM'nin önlendiği vurgulanmıştır (15). Diyet ile indüklenmiş obez farelerin kullanıldığı çalışmada $\mathrm{D}$ vitaminin ve kalsiyumun adipozite üzerine etkileri araştırılmış, yüksek doz D vitamini ve kasiyum alımı apoptozun indüksiyonu ve kalsiyum bağımlı apoptotik proteazların aktivasyonu ile ilişkili olduğu ve $\mathrm{D}$ vitamini ile birlikte kalsiyum verilmesinin adipoziteyi azaltmada daha etkili olduğu gösterilmiştir (16). Barengolts ve $\operatorname{ark}(17)$, çift kör, randomize ve vaka kontrollü prediayabetik ve D vitamini eksikliği olan Afro-Amerikan erkekleri dahil ettiği çalışmada, D vitamini desteği alan grupla plasebo grubu arasinda, 12 ay sonra oral glukoz insülin duyarlılı̆gı ile hemoglobin A1c açısından anlamlı bir fark tespit edilememiş ve glisemik sonuçları düzeltemediği göstrerilmişti. Bu çalışmalar sonucunda D vitamininin glukoz metabolizması üzerindeki etkileri aydınlatılmaya çalışılmış, hayvan deneylerinde başarılı sonuçlar alınsa da insanlarda etkilerin gösterilmesi için geniş kapsamlı çalışmalara ihtiyaç olduğu görülmüştür.

\section{Sinir Sistemi}

Multipl skleroz (MS); kronik, inflamatuvar, demiyelizan bir merkezi sinir sistemi hastalığıdır. Otoimmun hastalıklarda deneysel çalışmalar, D vitamininin immun sistem üzerindeki etkileri ortaya konulmaya başlandıktan sonra hız kazanmıştır. Cantorna ve ark.(18) in vivo olarak 1,25- $(\mathrm{OH})_{2} \mathrm{D}_{3}$ 'ün deneysel otoimmun ensefalomiyelit oluşumunu engellediğini göstermiştir. Cantorna ve ark.(19) yaptıkları diğer bir çalışmada ise $1,25-(\mathrm{OH})_{2} \mathrm{D}_{3}$ 'ün ve kalsiyumun immun cevabı düzenlediği desteklenmiş ve $1,25-(\mathrm{OH})_{2} \mathrm{D}_{3}$ 'ün yeterli veya yüksek doz kalsiyum alan dişi deneklerde deneysel otoimmün ensefalomiyelite karşı daha etkili olduğu gösterilmiştir. D vitamini merkezi sinir sistemi ve T lenfositler üzerinde bulunan reseptörü üzerinden etkili olmaktadır. Reseptörlerinin 1,25- $(\mathrm{OH})_{2} \mathrm{D}_{3}$ ile uyarılmış $\mathrm{T}$ hücreler ile up-regüle edilebilir (18).

Wergeland ve ark.(20) MS modeli oluşturulmuş fareler ile çalışarak diyetle alınan hidroksile olmamış D vitamini miktarlarının oligodendrosit kaybı, demiyelinizasyon ve remiyelinizasyon etkilerini araştırmışlardır. Bu çalışmada $\mathrm{D}$ vitamininin merkezi sinir istemi lökosit infiltrasyonundan bağımsız olarak demiyelinizasyon modelinde demiyelinizasyonu ve mikroglia aktivasyonu/makrofaj infiltrasyonunu hafiflettiği gösterilmiştir. Chabas ve ark.(21) ise ratları kullandıkları çalış- 
malarında kolekalsiferol ergokalsiferole göre, fonksiyonel iyileşmeyi artırmada daha etkili olarak bulunmuş ve aksogenez ve miyelinizasyonda rolü olan kalsitriol ile düzenlenen genleri ortaya koyulmuştur.

Amyotrofik lateral skleroz (ALS) motor korteksin nörodejeneratif bir hastalığıdır. Hastalığın patolojisinde $\mathrm{D}$ vitamininin etkili olduğu gösterilmiştir. Farelerin kullanıldığ ALS üzerine D vitamininin etkilerinin incelendiği çalışmada D vitamininin ALS tedavisinde kullanılabileceği sonucuna varmışlardır (22). Artmış kalsiyum alımı iskelet kasinda kontraktil protein sentezindeki artış ile kaslarda atrofinin azalmasina neden olmakta ve TNF- $\alpha$, IL-1 $\beta$ ve nitrik oksit sentaz azalmas1 ile inflamasyonun ve oksidatif stres hafiflemekte, prealbumin, kalbindin ve kalretinin artması ile glutamat toksisitesinde azalma ve mikrotübül ilişkili protein, büyüme ilişkili protein ve sinapsin proteinlerinde artma neticesinde nöronal kayıpta azalma ve ALS üzerinde potansiyel olumlu faktörler olabileceği görülmüştür (22).

\section{Kanser}

Kolon kanseri: Deneysel çalışmalarda kolorektal hücrelerinin de içinde olduğu birçok hücrede $\mathrm{D}$ vitamini reseptörünün ve $1-\alpha$ hidroksilazın eksprese edildiği gösterilmiştir (23). Diyetle alınan $\mathrm{D}$ vitaminin arttırılması kolorektal adenoma riskinde $\% 11$ azalmaya neden olmaktadır (24). Leysens ve ark.(25) 2015 yılında yayınladıkları çalışmalarında kolon kanseri hücre kültürü kullanmışlardır. Bu çalışmada sonuç olarak $1,25-(\mathrm{OH})_{2} \mathrm{D}_{3}$ ve analogları çeşitli kolon kanser hücre serilerinde fosfolipit kompozisyonu üzerinde yüksek oranda farklı etkileri gösterilmiştir. Ancak bu konu üzerinde daha fazla çalışma gerekmektedir.

Prostat kanseri: Prostat kanseri ile D vitamini arasındaki ilișki halen tartışmalıdır. Bir çok in vitro, hayvan deney ve ekolojik çalışmalar, yetersiz alınan D vitamini ile prostat kanser riskini artırdığını söylemektedir (26). Selenyum ve E vitamini kanser koruma çalışmasından (SELECT), D vitamini ve prostat kanseri riski sonuçları 2014 yılında yayınlanmıştır. Bu geniş çalışmada orta seviyeli konsantrasyonlarda (yaklaşık olarak 45-70 nmol/L) erkekler arasinda prostat kanser riskini anlamlı olarak azalttığ gösterilmiștir. Yüksek ya da düșük konsantrasyonda $\mathrm{D}$ vitamini konsantrasyonları ile özellikle yüksek dereceli prostat kanserinde artış izlenmiştir. Prostat kanserinden korunmada hangi populasyona ne kadar D vitamini desteği verilmelidir konusu belirgin olmasa da 50 yaşını geçmiş erkeklerde serum konsantrasyonu $70 \mathrm{nmol} / \mathrm{L}$ 'yi geçmeyecek şekilde D vitamin desteğinin sinırlanmasının uygun olduğu düşünülmektedir (27).

\section{Göz Hastalıkları}

Gözde D vitamininin hedef hücreleri ilk defa kalbindin ile retinada gösterilmiştir (28). Daha sonraki zamanlarda ise immunhistokimyasal boyamalar ile D vitamini reseptörleri kornea, lens, siliyer cisim ve retina pigment epitellerinde, kornea epitelinde, ganglion hücre tabakasinda ve retinal fotoreseptörlerde gösterilmiştir (29). Yakın zamanda korneal epitelyal ve endotelyal hücrelerde, skleral fibroblastlarda, siliyer cismin pigmentsiz epitelinde ve erişkin retinal pigment epitel hücre kültürlerinde vitamin $\mathrm{D}$ hidroksilaz aktivitesi varllğg ve bu hücrelerin bir çoğunun 25-(OH)D $\mathrm{D}_{3}$ 'ü aktif 1,25$(\mathrm{OH})_{2} \mathrm{D}_{3}$ forma dönüştürebildiği gösterilmiştir (30). İlginç olarak korneal limbal epitelyal hücre kültürlerinin UVB maruziyeti sonrası cilt hücrelerine benzer şekilde de novo $\mathrm{D}$ vitamini üretebildiği gösterilmiştir (31). Gözdeki diğer $\mathrm{D}$ vitamini kaynakları ise tavşanlarda oral D vitamini desteği ile D vitamini metabolitlerinin gösterildiği humor aköz, vitreus ve göz yaş1 film tabakasıdır (31). D vitaminin oküler sağllğı korumada önemli rolü olduğu düşünülmekte ve çeşitli hastaliklarda fizyopatolojideki ve potansiyel terapötik roldeki önemi araştırılmaktadır (31).

Miyopi: Epidemiyolojik çalışmaların gün 1şı̆̆ında geçirilen zamanın miyopiden koruyucu rolünün olduğunun göstermesi ile miyopide D vitaminin rolünü araştıran çalışmaların önü açılmiştır. Vitamin D reseptör (VDR) varyasyonları ile myopi riskinin ilişkisi de çalışılmıştır. VDR geni, miyopi ile ilişkili lokusun (MYP-3) çok yakıınında lokalizedir (32). Bunun yanı sira kalsiyum homeostazındaki deregülasyonun siliyer kasta disfonksiyona yol açarak emetropizasyonda probleme yol açtığ1 gösterilmiştir (33). Sonuç olarak şimdiye kadar yapılan çalışmalar D vitamin seviyesi ile miyopinin ilişkisini öne sürmektedir, ancak bu korumanın mekanizması ve biyolojik önemini açı̆̆a çıkaracak daha ileri çalışmalara ihtiyaç vardır (33).

Retinoblastom: İlk olarak 1966 y1linda spontan regresyon gösteren retinoblastomlarin $(\mathrm{Rb})$ siklikla kalsifikasyon gösterdiğinin gözlemlenmesi ile Verhoeff (34), D vitaminin tedavide etkili olabileceği hipotezini öne sürmüştür. D vitamininin kalsifikasyonu indüklemediği gösterilse de; hem in vitro deneylerde, hem de hayvan modellerinde tümoral hücre büyümesini inhibe ettiği gösterilmiştir $(35,36)$.

İnsan $\mathrm{Rb}$ dokusunda ve Luteinleştirici hormon (LH) beta-Tag transgenik farelerde (Simian virus 40 (SV40) antijen aşır1 ekspresyonunun insan retinal tumorünü indüklediği model) tümöral dokunun D Vitamini Reseptörü (VDR) eksprese ettiği gösterilmiştir (37). Bu da bu tümörlerin D vitamini tedavisine yanıt verebileceğini düşündürmüștür. 1,25- $(\mathrm{OH})_{2} \mathrm{D}_{3}$ tedavisinin, G0/G1 hücre döngüsü arresti, apoptozis ve programlı tümöral hücre ölümü indüksiyonu ile Y79 hücre büyümesini in vitro inhibe ettiği gösterilmiştir (38). 1,25- $(\mathrm{OH})_{2} \mathrm{D}_{3}$ 'ün ayn zamanda Bcl-2-associated $\mathrm{X}$ protein (Bax) proteinini arttırdığı, B-cell lymphoma 2 (Bcl-2= ekspresyonunu ise azalttığ1 gösterilmiştir. Hastalığın hem ksenograft hem de transgenik modellerinde 5 haftalık $1,25-(\mathrm{OH})_{2} \mathrm{D}_{3}$ uygulamasinın anlamlı olarak tümor büyümesini inhibe ettiği gösterilmiștir (39). Tedavi kanser hücrelerinin apoptozisini arttırmış, anjiogenezi inhibe etmiştir. Güncel çalıșmalar aynı koruyucu etkinliğe ancak daha düşük kalsemik etkinliğe sahip VDR agonistleri çalışmalarına ve çok düşük doz D vitaminin kemoterapi etkinliğini arttırmasına yönelik kombinasyon tedavileri üzerinedir. Bir çalışmada sisplatin ile kombine 1,25- 
$(\mathrm{OH})_{2} \mathrm{D}_{3}$ uygulamasinin her hangi bir mortalite ya da böbrek toksisitesi görülmeksizin anlamlı olarak tümör büyümesini azalttığı gösterilmiştir (40).

\section{Yaşa bağlı makula dejenerasyonu} (YBMD): Tipik olarak bir inflamatuar hastalık olarak değerlendirilmese de kompleman aktivasyonu, immün hücre birikimi ve proinflamatuar sitokin salınımının YBMD gelişiminde rol oynadığı bilinmektedir. Çeşitli epidemiyolojik çalışmalarda serum D vitamini seviyesinin YBMD prevalans1 ve riski ile ilișkisi gösterilmiștir. Optik koherens tomografi çalışmaları ile D vitamini eksikliğinin özellikle makula kalınlığında azalma ve subretinal fibrozis ile ilişkili olduğu gösterilmiştir (41,42). D vitamini ile YBMD prevalansı metabolizması arasında genetik bir ilişki olduğunu gösteren bir çok çalışma vardır. YBMD gelişiminde kuvvetli risk faktörleri olarak bildirilen bir takım genetik varyasyonlar mevcuttur. Bu lokuslardan birinde HTRA1 (Hightemperature requirement factor A1) geninin promoter bölgesinde bulunan bir tek nükleotid polimorfizminin (SNP) YBMD gelişimi yatkınlı̆̆ını anlamlı olarak arttırdığı görülmüştür (43).

$\mathrm{D}$ vitamini tedavisi ile fare retinalarındaki neovaskülarizasyonun ve inflamatuar olayların incelendiği çeşitli çalışmalar mevcuttur. Lee ve ark. (44) yaşlanan farelerdeki çalışmalarında subkutan D vitamini tedavisinin retinal inflamasyonu anlamlı olarak azalttığ gösterilmiştir. Tedavi alan farelerde subretinal boșlukta daha az makrofaj, Bruch membraninda daha az kompleman birikimi ve retinal amiloid beta birikiminde azalma görülmüştür. Oksijen ile indüklenen iskemi retinopati modelinin geliştirildiği bir fare modelinde intraperitoneal $\mathrm{D}$ vitamini tedavisinin doz bağımlı olarak retinal neovaskülarizasyonu inhibe ettiği gösterilmiştir (45). Sonuç olarak bu fare modelleri azalmış D vitamininin YBMD gelişimindeki mekanizmasını da açıklayabilecek şekilde göstermektedir ki, D vitamini desteği retinada anjiogenez ve inflamasyon açısından koruyucu etkiler oluşturmaktadır.
Diabetik retinopati: Çeşitli epidemiyolojik çalışmalarda D vitamini seviyesi düşüklüğünün diabetik retinopati evresi ile korele bir şekilde ilişkili olduğu gösterilmiştir. Ayrıca VDR genetik varyasyonu ile de ilişki çalışmalarda gösterilmiştir ().

Ren ve ark. (46) tip 2 DM'lu rat modeli kullandıkları çalışmalarında D vitamini ile tedavi edilen ratlarda azalmış VEGF ve TGF- $\beta 1$ ekspresyonu tespit etmişlerdir. Histolojik çalışmalarda da retinada koruyucu etkiler gösterilmiştir. D vitaminin koruyucu mekanizmalarının ve direk olarak neovaskülarizasyon inhibisyonu etkisinin olup olmadığının aydınlatılması için ileri çalışmalara ihtiyaç vardır.

Üveit: Behçet hastalarında ve HLA-B27 antijeni pozitif bireylerde D vitamini metabolizması ile üveit gelişiminin ilişkili olduğunu gösteren çeşitli çalışmalar vardır. Deneysel otoimmün üveit geliştirilen fare modellerinde oral $\mathrm{D}$ vitamini tedavisinin hastalığın gelişimini engellediği ve indüklenmiş retinal otoimmüniteyi zayıflattığ1 gösterilmiştir (47). Hem bu çalışmadaki fare modelinde hem de Behçet hastalığ1 olan insan örneklerinde D vitamini tedavisinin, retinal inflamasyondan sorumlu olan Th17 cevabını inhibe ettiği gösterilmiştir $(47,48)$. Bu çalışmalarla D vitamini tedavisinin yalnızca aktif inflamasyon durumunda değil üveitin önlenmesinde de etkili olabileceği gösterilmiştir ().

Glokom: Glokom ve D vitamini seviyesi arasındaki ilişkisinin çalışıldığı epidemiyolojik çalışmaların sonuçları çelişkilidir. Kutuzova ve ark.(49) fare ve rat çalışmalarında D vitamini tedavisinin göz içi basıncı ilişkili genlerin modülasyonunda etkisi olduğunu göstermiş ve topikal $1,25-(\mathrm{OH})_{2} \mathrm{D}_{3}$ tedavisinin göz içi basıncında anlamlı düşmeye neden olduğunu belirtmişlerdir.

\section{Bağıșıklık sistemi ve Enfeksiyonlar}

Vitamin D eksikliği ile enfeksiyonlara yatkınlık arasındaki ilişki uzun yıllar boyunca araştırmalara konu olmuştur (50). Vitamin D hem doğal hem de kazanılmıs immünitede önemli rol oynar. Vitamin D'nin vücut savunma mekanizmasındaki rolü ile ilgili farklı teoriler vardır. Bunlardan bazıları; cilt, gastrointestinal sistem, solunum yolu ve genitoüriner sistemin yaralanma ve mikroorganizmaların invazyonundan korunmas1, insan monositlerinde hidrojen peroksit sekresyonunun aktive edilmesi ve oksidatif patlama potansiyelini arttırmas1, immün hücrelerin yara iyilesmesini sürdürmesi veya enfeksiyonla mücadelesini arttırmasıdır $(50,51)$. Bu etkiyi açıllayan çeşitli bilgiler mevcuttur. Lokal aktif sitokinler gibi, immün hücrelerde sentezlenen aktif $\mathrm{D}$ vitamininin immün modülatör etkileri vardır. Hayvan modelleri ve in vitro çalışmalar ile $\mathrm{D}$ vitamininin aktif formu proinflamatuvar yardımc1 $T$ hücreleri Th1 ve Th17 cevaplarını baskıladığı, Interleukin 4 (IL-4), Interleukin 5 (IL-5) ve Interleukin-10 (IL-10) üretiminin arttır1masıyla Th2 ve düzenleyici $\mathrm{T}$ hücre fenotipini desteklediği gösterilmiştir $(52,53)$. Randomize plasebo kontrollü yapılan bir diğer çalışmada ise yüksek doz kolekalsiferol desteğinin CD4 pozitif regülator $T$ hücreler üzerine etkileri araştırılmış ve yüksek $25(\mathrm{OH}) \mathrm{D}$ vitamini seviyesinin otoimmün hastalıklarda önemli olan regülator $\mathrm{T}$ hücrelerinde belirgin artıșa neden olduğu gösterilmiştir (4).

D vitamini yetersizligi ile enfeksiyöz hastalıklar arasındaki ilişkinin en belirgin olduğu tablo tüberküloz hastalığıdır. Serum $25(\mathrm{OH})$ D düzeylerinde düşüklük ile tüberküloz enfeksiyonuna yatkınlık arasında kuvvetli ilişki olduğu, intrasellüler tüberküloz basilinin öldürülmesinin sağlanmasında vitamin D'nin önemli olduğu çeşitli çalışmalarda gösterilmiştir (54). Yine yakın zamanda yayınlanan bir metaanalizde yoğunbakım hastalarında yaygin olarak $25(\mathrm{OH}) \mathrm{D}$ defekti olduğu, bunun da enfeksiyon ve sepsis için risk faktörü oluşturduğu ve bu eksikliğin mortalite ile ilişkili olduğu raporlanmıştır (55). 1,25(OH) D vitamini ile bronşial epitel hücrelerinin antibakteriyel aktivitelerinin arttı̆̆1 gösterilmiş ve bu nedenle ağır akciğer enfeksiyonları nedeni ile sik hastaneye yatış hikayesi ve antibiyotik kullanımı olan kistik fibrozisli hastalarda inhale 
1,25 (OH) D vitamini kullanımı gündeme gelmiştir (56). Çeşitli çalışmalarda optimal vitamin $\mathrm{D}$ düzeyine sahip konakların, viral respiratuar hastalıklarda immünregülatuar fonksiyonunu aşırı sitokin yanıtının engellenmesi ve çeşitli mikroorganizlamaların uzaklaştırılması ile sağladığı gösterilmiştir (57).

Ayrica D vitamini, Helicobakter pylori enfeksiyonundaki inflamasyonun kontrolünde de önemlidir. Aktif D vitamini kullanımı ile Helicobakter pylo$r i$ enfeksiyonlarında \% 50'den fazla azalma çalışmalarda gösterilmiştir (58). Çok yakın dönemde Wong ve ark.(59) Vitamin D düzeyi ve uzamış Clostridium difficile enfeksiyonlar1 arasında anlamlı bir ilişki bulunduğunu raporlamışlardır. Ayrıca HIV infeksiyonu olan hastalarda düşük serum D vitamini düzeyi ile mortalite artışı arasındaki ilişki net olarak ortaya konmuş olup $\mathrm{D}$ vitaminin $\mathrm{T}$ hücre fonksiyonlarını indüklediği ve antiviral etkinlikte bulunduğu görülmüştür (60).

Paraziter, fungal ve protozoal enfeksiyonlarda vitamin D'nin immünmodülatuar etkisi ile ilgili veriler kısıtlıdır. Bundan dolayı farklı sinıf enfeksiyon hastalıklarında sitokin yanitı, konak vitamin $\mathrm{D}$ düzeyi ve konak-patojen ilişkisi arasındaki dengenin anlaşılabilmesi için ileri çalışmalara ihtiyaç duyulmaktadir).

\section{Geriatrik populasyon ve $D$ vitamini}

Vitamin D eksikliği diğer yaşlarda olduğu gibi 65 yaş üstü kişilerde de sıklıkla görülmekte ve bu durum kas gücünü ve hareket yeteneğini büyük oranda etkilemektedir. Literatürde güneşten yararlanma oranı yüksek bölgelerde ve ülkelerde bile 65 yaş üstü bireylerde Vitamin D eksikliği olduğu ve kişilerin genel durumu olumsuz yönde etkilediği bildirilmiştir (61). Çalışmalarda Vitamin D eksikliğinin yaşlılarda neden olduğu önemli durumlardan biri olan kas-iskelet sistemi üzerine odaklanılmıştır. Ancak bilinmektedir ki birçok hücrenin yapısında Vitamin $\mathrm{D}$ reseptörleri bulunmaktadır ve bu durum Vitamin D eksikliğine bağlı olarak diğer sistemlerde görülen hastalıklara yatkınlığı artırmaktadır (62).

Yaşll1ıkta Vitamin D eksikliğinin neden olduğu kas-iskelet sistemi dişı hastalıklarla ilgili henüz kanıt düzeyi yeterli değildir ve bu konuda farklı görüşleri ortaya sunan çalışmalar bulunmaktadir. Kendrick ve ark. (63) çalışmasında yetişkin bireylerde Vitamin D eksikliğinin kardiyovasküler hastalık görülme oranında artışa neden olduğu, Cigolini ve ark. (64) çalışmasında ise ortalama yaşları 61 olan Tip 2 DM'li bireylerde vitamin $\mathrm{D}$ eksikliği ve kardiyovasküler hastalık görülme arasında ilişki olduğu bildirilmiştir. Vitamin D eksikliğinin kardiyovasküler hastalık görülme oranında artışa neden olduğu özellikle de hipertansiyon sıkl1ğında artışa neden olduğu ile ilgili çalışmalar bulunmaktadır. Vitamin D eksikliğinin tedavi edilmesi kan basıncını düzenlemeye yardımcı olur (65). Soysal ve ark. (66) yaptığı bir çalışmada ise serum Vitamin D düzeyi eksikliğinin ortostatik hipotansiyonla ilişkili olabileceği yönündedir. Yine vitamin $\mathrm{D}$ eksikliğinin bir diğer kronik hastalık olan Tip 2 diabetes mellitusta artışa neden olduğu bildirilmiştir. Tip 2 DM yaşlilarda siklıkla görülmektedir ve vitamin $\mathrm{D}$ takviyesinin DM nedeni olan insülin duyarlılığında azalmayı tedavi ettiği ve duyarlılı̆̆1 artırdığı bildirilmiştir (67).

Yapılan çalışmalarda depresyon ve vitamin D seviyeleri arasında ilişki olduğu depresyondaki yaşlilarda vitamin D seviyelerinin düşük olduğu belirtilmiştir (68). Gronli ve ark. (69) çalışmasında da psikiyatrik hastalıklarla Vitamin D arasında ilişki olduğu sadece depresyon değil diğer psikiyatrik hastalığ1 olan 64 yaş üstü bireylerde de vitamin D seviyesinin düşük olduğu saptanmıştır.

Ayrica D vitamini takviyesinin inflamasyonu baskıladığ1, oksidatif stres biyomarkerlarını artırdığ1 yönünde çalişmalar mevcut olup, serum vitamin D seviyesinin artmasi total antioksidan kapasiteyi artırıp ve CRP seviyelerini düşürür (70). Yine yapılan çalışmalarda vitamin D replasmanının kanseri, kansere bağlı mortaliteyi ön- lediği ya da kanser tedavisinde olumlu etkiler yarattığı ile ilgili bulgular mevcuttur. Bunlar arasında özellikle yaşlılıkta sık görülen kolon, prostat ve göğüs kanseri yer almaktadır (71). Ayr1ca son çalışmalarda yaşlılarda vitamin D megadoz uygulamalarının (200.000 IU/gün) total antioksidan kapasiteyi arttırdığ1 ve sistemik inflamasyonu azalttığ1 (CRP azalmaktadır) gösterilmiştir (72).

\section{Metabolik Sendrom}

Metabolik sendrom patofizyolojisinde D vitamin eksikliği anahtar rol almaktadır. Vitamin D eksikliği kardiovasküler sistemi etkiler, insulin direncini arttırır, renin-anjiotensin-aldosteron sistemini stimule ederek hipertansiyona yol açmaktadır. Vücutta tüm hücreler ama özellikle immun sistem hücreleri, vasküler ve myokardiyal hücreler, pankreas beta hücreleri, nöronlar ve osteoblastlar üzerindeki D vitamini reseptörlerinin keșfedilmesi ile metabolik sendrom D vitamini arasındaki ilişki açığa çıkmıştır. Metabolik sendromda abdominal obezite, aterojenik dislipidemi, hipertansiyon ve insülin direnci birlikteliği bulunmaktadır. Kardiovasküler hastalıklar ve Tip 2 DM riski çok artmıştır (73).

Hipertansiyon: Kunutsor ve ark. (74) yapmış oldukları bir meta analizde serum vitamin $\mathrm{D}$ düzeyleri ile hipertansiyon insidansı aras1 ters korelasyon bulunmuştur. Bir diğger çalışmada düşük $\mathrm{D}$ vitamin düzeyi $(<15 \mathrm{ng} / \mathrm{mL})$ olan hastalarda optimal D vitamin düzeyi olan kişilere göre 4 y1llık takipte H'T gelişme riski 3-6 kat yüksek bulunmuştur (75). İngiltere'den yap1lan geniş bir Kohort çalışmasında da HT içeren metabolic sendrom ile serum $\mathrm{D}$ vitamin düzeyleri arasında ters korelasyon saptanmıştır (76). 283 siyah Amerikalı üzerinde vitamin D alımı ile HT riski arasındaki ters korelasyon gösterilmiştir. Katılan deneklere 1000,2000 ve 4000 IU günlük D vitamini veya placebo 3 ay boyunca verilmiş ve $\mathrm{D}$ vitamin desteği alan grupta her $1 \mathrm{ng} / \mathrm{mL} \mathrm{D}$ vitamin artış1nın sistolik kan basıncinda $0.2 \mathrm{mmHg}$ azalma yaptığı gösterilmiştir (77). 
Obezite: Obezite ve D vitamini yetersizliği arasındaki ilişki net olarak bilinmektedir. 42,024 denek üzerinde yapilan bir çalışmada beden kitle indeksindeki her birim artış $25(\mathrm{OH}) \mathrm{D}$ vitamininde \%1.15 azalmaya neden olmaktadır (78). Düşük D vitamin düzeyleri yüksek beden yağı, kan şekeri ve azalmış insulin sensivitesi düzeyleri ile ilişkilidir ayrıca D vitamin düşüklüğü ve parathormon yüksekliğinin aterojenik dislipidemi ve yüksek metabolik sendrom riski ile ilişkili olduğu da gösterilmiştir $(79,80)$. Oniki hafta boyunca günlük 1000 IU D vitamin replasmanı yapılan obez kadınlarda beden yağının azaldığ1 gösterilmiştir (81). Carrillo ve ark.da (82) obezlerde günlük 4000 IU D vitamin replasmanının bel kalça oranını azalttığını göstermişlerdir.

Insülin sensivitesi: Literatürde D vitamin yetersizliği ile insulin direnci ya

\section{KAYNAKLAR}

1. Wranicz J, Szostak-Wegierek D. Health outcomes of vitamin D. Part I. characteristics and classic role. Roczniki Panstwowego Zakladu Higieny. 2014;65(3):179-84. PubMed PMID: 25247796.

2. Holick MF. Vitamin D deficiency. The New England journal of medicine. 2007;357(3):266-81. PubMed PMID: 17634462 .

3. Holick MF, Binkley NC, BischoffFerrari HA, Gordon CM, Hanley DA, Heaney RP, et al. Evaluation, treatment, and prevention of vitamin D deficiency: an Endocrine Society clinical practice guideline. The Journal of clinical endocrinology and metabolism. 2011;96(7):1911-30. PubMed PMID: 21646368.

4. Prietl B, Treiber G, Mader JK, Hoeller E, Wolf M, Pilz S, et al. High-dose cholecalciferol supplementation significantly increases peripheral CD4(+) Tregs in healthy adults without negatively affecting the frequency of other immune cells. European journal of nutrition. 2014;53(3):751-9. PubMed PMID: 23999998.

5. Malek HA, Shata A. Effect of a high dose of vitamin D on a rabbit model of da bozulmuş insulin sekresyonu arasında ilişki olduğu öne sürülmüştür $(83,84) .17$ y1l takipli bir çalışmada $25(\mathrm{OH}) \mathrm{D}$ düzeyi $28 \mathrm{ng} / \mathrm{mL}$ ve üzeri olan populasyonda Tip $2 \mathrm{DM}$ gelişme riskinin \%40 azaldığ1 gösterilmiştir (85). Randomize kontrollü bir çalışmada 12 hafta boyunca günlük 4000 IU D vit. replasmanı alan prediabetik obezlerde insulin sekresyon ve sensivtivitesinin düzeldiği gösterilmiştir (86).

Dislipidemi: Vitamin D yetersizliği ile düşük HDL, yüksek trigliserid, apolipoprotein $\mathrm{E}$ ve hiperkolesterolemi arasında net bir ilişki bulunmaktadır $(87,88)$. Chai ve ark. (89) altı ay boyunca kalsiyum (2 $\mathrm{g}$ /gün) ve $\mathrm{D}$ vitamin (800 IU/gün) kombinasyonunu alanlarda yalnızca D vitamini replasmanı alan kişilere göre serum lipid düzeylerinde anlamlı düşme olduğunu saptamışlardır.

atherosclerosis. International journal of immunopathology and pharmacology. 2014;27(2):195-201. PubMed PMID: 25004831 .

6. Bas A, Lopez I, Perez J, Rodriguez M, Aguilera-Tejero E. Reversibility of calcitriol-induced medial artery calcification in rats with intact renal function. Journal of bone and mineral research : the official journal of the American Society for Bone and Mineral Research. 2006;21(3):484-90. PubMed PMID: 16491297.

7. Haffner D, Hocher B, Muller D, Simon $\mathrm{K}$, Konig $\mathrm{K}$, Richter $\mathrm{CM}$, et al. Systemic cardiovascular disease in uremic rats induced by $1,25(\mathrm{OH}) 2 \mathrm{D} 3$. Journal of hypertension. 2005;23(5):1067-75. PubMed PMID: 15834294 .

8. Li F, Liu P, Zhang X, Zhang Q, Tang S, $\mathrm{Zhu} \mathrm{M}$, et al. 1,25(OH)2D3-mediated amelioration of aortic injury in streptozotocin-induced diabetic rats. Inflammation. 2013;36(6):1334-43. PubMed PMID: 23813327.

9. Pittas AG, Dawson-Hughes B. Vitamin $\mathrm{D}$ and diabetes. The Journal of steroid biochemistry and molecular biology. 2010;121(1-2):425-9. PubMed PMID:

\section{SONUÇ}

Günümüze kadar deneysel olarak birçok çalışma ile D vitaminin çeşitli hastalıkların tedavisinde etkileri araştırılmıştır. Sonuç olarak hiperkalsemik etkilerinin ortaya çıkmadığı dozlarda diyetle alınan destek D vitamini, damar hastalıkları, DM, MS, ALS, metabolik sendrom gibi bir çok kronik hastalıkta umut vermektedir. Ancak henüz günümüzde $\mathrm{D}$ vitamini eksikliğinin taranma ve tedavisi ile ilgili bir guideline bulunmamaktadır. Dolay1siyla hangi hastaya, hangi risk faktörleri varlığında ve hangi dozda D vitamin desteği önerilmesi gerektiği konusu ise belirsizdir. Güncel data göstermektedir ki en iyi sağllk sonuçları için serum $25(\mathrm{OH}) \mathrm{D}$ vitamini düzeylerinin 75-100 nm/L aralığında olması arzulanmaktadır (90). Referans olmaz kendi, görüşünüz olmalı

20304061. Pubmed Central PMCID: 2900448.

10. Wu-Wong JR, Nakane M, Ma J, Ruan X, Kroeger PE. Effects of Vitamin D analogs on gene expression profiling in human coronary artery smooth muscle cells. Atherosclerosis. 2006;186(1):208. PubMed PMID: 16095599.

11. Zehnder D, Bland R, Chana RS, Wheeler DC, Howie AJ, Williams MC, et al. Synthesis of 1,25dihydroxyvitamin $\mathrm{D}(3)$ by human endothelial cells is regulated by inflammatory cytokines: a novel autocrine determinant of vascular cell adhesion. Journal of the American Society of Nephrology : JASN. 2002;13(3):621-9. PubMed PMID: 11856765 .

12. Lamawansa MD, Wysocki SJ, House AK, Norman PE. Vitamin D3 exacerbates intimal hyperplasia in balloon-injured arteries. The British journal of surgery. 1996;83(8):1101-3. PubMed PMID: 8869314.

13. Mathieu C, Badenhoop K. Vitamin D and type 1 diabetes mellitus: state of the art. Trends in endocrinology and metabolism: TEM. 2005;16(6):261-6. PubMed PMID: 15996876. 
14. Wang G, Hu C, Hu C, Ruan L, Bo Q, Li L. [Impact of oral vitamin D supplementation in early life on diabetic mice induced by streptozotocin]. Wei sheng yan jiu $=$ Journal of hygiene research. 2013;42(3):455-9. PubMed PMID: 23805526.

15. Takiishi T, Ding L, Baeke F, Spagnuolo I, Sebastiani G, Laureys J, et al. Dietary supplementation with high doses of regular vitamin D3 safely reduces diabetes incidence in NOD mice when given early and long term. Diabetes. 2014 Jun;63(6):2026-36. PubMed PMID: 24550187.

16. Sergeev IN, Song Q. High vitamin D and calcium intakes reduce diet-induced obesity in mice by increasing adipose tissue apoptosis. Molecular nutrition \& food research. 2014;58(6):1342-8. PubMed PMID: 24449427.

17. Barengolts E, Manickam B, Eisenberg Y, Akbar A, Kukreja S, Ciubotaru I. Effect of High-Dose Vitamin D Repletion on Glycemic Control in African American Men with Prediabetes and Hypovitaminosis D. Endocrine practice : official journal of the American College of Endocrinology and the American Association of Clinical Endocrinologists. 2015;25:130. PubMed PMID: 25716637.

18. Cantorna MT, Hayes CE, DeLuca HF. 1,25-Dihydroxyvitamin D3 reversibly blocks the progression of relapsing encephalomyelitis, a model of multiple sclerosis. Proceedings of the National Academy of Sciences of the United States of America. 1996;93(15):7861-4. PubMed PMID: 8755567. Pubmed Central PMCID: 38839.

19. Cantorna MT, Humpal-Winter J, DeLuca HF. Dietary calcium is a major factor in 1,25-dihydroxycholecalciferol suppression of experimental autoimmune encephalomyelitis in mice. The Journal of nutrition. 1999;129(11):1966-71. PubMed PMID: 10539770.

20. Wergeland S, Torkildsen O, Myhr KM, Aksnes L, Mork SJ, Bo L. Dietary vitamin D3 supplements reduce demyelination in the cuprizone model. PloS one. 2011;6(10):e26262. PubMed PMID: 22028844.

21. Chabas JF, Stephan D, Marqueste T, Garcia S, Lavaut MN, Nguyen C, et al. Cholecalciferol (vitamin D(3)) improves myelination and recovery after nerve injury. PloS one. 2013;8(5):e65034. PubMed PMID: 23741446.

22. Gianforcaro A, Hamadeh MJ. Vitamin $\mathrm{D}$ as a potential therapy in amyotrophic lateral sclerosis. CNS neuroscience \& therapeutics. 2014;20(2):101-11. PubMed PMID: 24428861.

23. Peterlik M, Cross HS. Vitamin D and calcium deficits predispose for multiple chronic diseases. European journal of clinical investigation. 2005;35(5):290304. PubMed PMID: 15860041.

24. Wei MY, Garland CF, Gorham ED, Mohr SB, Giovannucci E. Vitamin D and prevention of colorectal adenoma: a meta-analysis. Cancer epidemiology, biomarkers \& prevention : a publication of the American Association for Cancer Research, cosponsored by the American Society of Preventive Oncology. 2008;17(11):2958-69. PubMed PMID: 18990737.

25. Leyssens C, Marien E, Verlinden L, Derua R, Waelkens E, Swinnen JV, et al. Remodeling of phospholipid composition in colon cancer cells by 1alpha, 25(OH)D and its analogs. The Journal of steroid biochemistry and molecular biology. 2015;148:172-8. PubMed PMID: 25625664.

26. Chen TC, Holick MF. Vitamin D and prostate cancer prevention and treatment. Trends in endocrinology and metabolism: TEM. 2003;14(9):423-30. PubMed PMID: 14580762.

27. Kristal AR, Till C, Song X, Tangen CM, Goodman PJ, Neuhauser ML, et al. Plasma vitamin D and prostate cancer risk: results from the Selenium and Vitamin E Cancer Prevention Trial. Cancer epidemiology, biomarkers \& prevention : a publication of the American Association for Cancer Research, cosponsored by the American Society of Preventive Oncology. 2014;23(8):1494-504. PubMed PMID: 24732629. Pubmed Central PMCID: 4119495 .

28. Verstappen A, Parmentier M, Chirnoaga M, Lawson DE, Pasteels JL, Pochet R. Vitamin D-dependent calcium binding protein immunoreactivity in human retina. Ophthalmic research. 1986;18(4):209-14. PubMed PMID: 3534678 .
29. Johnson JA, Grande JP, Roche PC, Campbell RJ, Kumar R. Immunolocalization of the calcitriol receptor, calbindin-D28k and the plasma membrane calcium pump in the human eye. Current eye research. 1995;14(2):101-8. PubMed PMID: 7539352.

30. Alsalem JA, Patel D, Susarla R, CocaPrados M, Bland R, Walker EA, et al. Characterization of vitamin $D$ production by human ocular barrier cells. Investigative ophthalmology \& visual science. 2014;55(4):2140-7. PubMed PMID: 24576880.

31. Lin Y, Ubels JL, Schotanus MP, Yin Z, Pintea V, Hammock BD, et al. Enhancement of vitamin D metabolites in the eye following vitamin D3 supplementation and UV-B irradiation. Current eye research. 2012 Oct;37(10):871-8. PubMed PMID: 22632164.

32. Annamaneni S, Bindu CH, Reddy KP, Vishnupriya S. Association of vitamin D receptor gene start codon (Fok1) polymorphism with high myopia. Oman journal of ophthalmology. 2011;4(2):57-62. PubMed PMID: 21897619.

33. Dulhunty AF, Beard NA, Pouliquin P, Kimura T. Novel regulators of RyR $\mathrm{Ca} 2+$ release channels: insight into molecular changes in genetically-linked myopathies. Journal of muscle research and cell motility. 2006;27(5-7):351-65. PubMed PMID: 16909197.

34. Verhoeff FH. Retinoblastoma undergoing spontaneous regression. Calcifying agent suggested in treatment of retinoblastoma. American journal of ophthalmology. 1966;62(3):573-4. PubMed PMID: 5922000.

35. Albert DM, Marcus DM, Gallo JP, O'Brien JM. The antineoplastic effect of vitamin $\mathrm{D}$ in transgenic mice with retinoblastoma. Investigative ophthalmology \& visual science. 1992;33(8):2354-64. PubMed PMID: 1634333 .

36. Sabet SJ, Darjatmoko SR, Lindstrom MJ, Albert DM. Antineoplastic effect and toxicity of 1,25-dihydroxy-16-ene23-yne-vitamin D3 in athymic mice with Y-79 human retinoblastoma tumors. Archives of ophthalmology. 1999;117(3):365-70. PubMed PMID: 10088815 . 
37. Suarez F, Jockovich ME, Hernandez E, Feuer W, Parel JM, Murray TG. Paclitaxel in the treatment of retinal tumors of LH beta-Tag murine transgenic model of retinoblastoma. Investigative ophthalmology \& visual science. 2007;48(8):3437-40. PubMed PMID: 17652710.

38. Wagner N, Wagner KD, Schley G, Badiali L, Theres H, Scholz H. 1,25dihydroxyvitamin D3-induced apoptosis of retinoblastoma cells is associated with reciprocal changes of $\mathrm{Bcl}-2$ and bax. Experimental eye research. 2003;77(1):1-9. PubMed PMID: 12823982

39. Audo I, Darjatmoko SR, Schlamp CL, Lokken JM, Lindstrom MJ, Albert DM, et al. Vitamin D analogues increase p53, p21, and apoptosis in a xenograft model of human retinoblastoma. Investigative ophthalmology \& visual science. 2003;44(10):4192-9. PubMed PMID: 14507860 .

40. Kulkarni AD, van Ginkel PR, Darjatmoko SR, Lindstrom MJ, Albert DM. Use of combination therapy with cisplatin and calcitriol in the treatment of Y-79 human retinoblastoma xenograft model. The British journal of ophthalmology. 2009;93(8):1105-8. PubMed PMID: 19336429.

41. Graffe A, Beauchet O, Fantino B, Milea D, Annweiler C. Vitamin D and macular thickness in the elderly: an optical coherence tomography study. Investigative ophthalmology \& visual science. 2014;55(8):5298-303. PubMed PMID: 25028353.

42. Singh A, Falk MK, Subhi Y, Sorensen TL. The association between plasma 25hydroxyvitamin $\mathrm{D}$ and subgroups in age-related macular degeneration: a cross-sectional study. PloS one. 2013;8(7):e70948. PubMed PMID: 23923033 .

43. Tong Y, Liao J, Zhang Y, Zhou J, Zhang H, Mao M. LOC387715/HTRA1 gene polymorphisms and susceptibility to age-related macular degeneration: A HuGE review and meta-analysis. Molecular vision. 2010;16:1958-81. PubMed PMID: 21031019. Pubmed Central PMCID: 2956667.

44. Lee V, Rekhi E, Hoh Kam J, Jeffery G. Vitamin $\mathrm{D}$ rejuvenates aging eyes by reducing inflammation, clearing amyloid beta and improving visual function. Neurobiology of aging. 2012;33(10):2382-9. PubMed PMID 22217419 .

45. Albert DM, Scheef EA, Wang S, Mehraein F, Darjatmoko SR, Sorenson $\mathrm{CM}$, et al. Calcitriol is a potent inhibitor of retinal neovascularization. Investigative ophthalmology \& visual science. 2007;48(5):2327-34. PubMed PMID: 17460298 .

46. Ren Z, Li W, Zhao Q, Ma L, Zhu J. The impact of 1,25-dihydroxy vitamin D3 on the expressions of vascular endothelial growth factor and transforming growth factor-beta(1) in the retinas of rats with diabetes. Diabetes research and clinical practice. 2012;98(3):474-80. PubMed PMID: 23089551 .

47. Tang J, Zhou R, Luger D, Zhu W, Silver PB, Grajewski RS, et al. Calcitriol suppresses antiretinal autoimmunity through inhibitory effects on the Th17 effector response. Journal of immunology. 2009;182(8):4624-32. PubMed PMID: 19342637.

48. Tian Y, Wang C, Ye Z, Xiao X, Kijlstra A, Yang $P$. Effect of 1,25dihydroxyvitamin D3 on Th17 and Th1 response in patients with Behcet's disease. Investigative ophthalmology \& visual science. 2012 Sep;53(10):643441. PubMed PMID: 22918640.

49. Kutuzova GD, Gabelt BT, Kiland JA, Hennes-Beann EA, Kaufman PL, DeLuca HF. 1alpha,25Dihydroxyvitamin $\mathrm{D}(3)$ and its analog, 2-methylene-19-nor-(20S)-1alpha,25dihydroxyvitamin $\mathrm{D}(3) \quad$ (2MD), suppress intraocular pressure in nonhuman primates. Archives of biochemistry and biophysics. 2012;518(1):53-60. PubMed PMID 22198282

50. Alexandra V. Yamshchikov, Nirali S Desai, Henry M. Blumberg, Thomas R. Ziegler and Vin Tangpricha. Vitamin D for treatment and prevention of infectious diseases: A systematic review of randomized controlled trials. National Institute of Health , 2009 ; 15(5): 438449.

51. Von Essen MR, Kongsback M, Schjerling P, Olgaard K. Vitamin D controls T cell antigen receptor signaling and activation of human $T$ cells. Nat Immunol 2010;11: 344-349.
52. Adorini L, Penna G. Dendritic cell tolerogenicity: a key mechanism in immunomodulation by vitamin D receptor agonists. Human immunology. 2009 May;70(5):345-52. PubMed PMID: 19405173.

53. Jeffery LE, Burke F, Mura M, Zheng $Y$, Qureshi OS, Hewison M, et al. 1,25Dihydroxyvitamin D3 and IL-2 combine to inhibit $\mathrm{T}$ cell production of inflammatory cytokines and promote development of regulatory $\mathrm{T}$ cells expressing CTLA-4 and FoxP3. Journal of immunology. 2009;183(9):5458-67. PubMed PMID: 19843932.

54. Liu PT, Stenger S, Li H, Wenzel L, Tan BH, Krutzik SR. Tool-like receptor triggering of a vitamin D-mediated human antimicrobial response. Science 2006;311: 1770-1773.

55. Haan K, Groeneveld AB J, Geus H RH, Egal M, Strujs A. Vitamin D deficiency as arisk factor for infection, sepsis and mortality in the critically ill: systematic review and meta-analysis. Critical Care 2014; 18: 660.

56. Walker VP, Modlin RL. The vitamin D connection to pediatric infections and immune function. Pediatr Res 2009; 5: 106R-113R

57. Cannell JJ, Vieth R, Umhau JC, Holick MF, Grant WB, Madronich S, et al. Epidemic influenza and vitamin D. Epidemiol Infect 2006;134:1129-1140. PubMed PMID: 16959053

58. Kawaura A. Inhibitory effect of long term 1alpha-hydroxyvitamin D3 administration on Helicobacter pylori infection. J Clin Biochem Nutr 2006;38: 103106

59. Wong KK, Lee R, Watkins RR, Haller NH. Prolonged Clostridium difficile infection may be associated with Vitamin D deficiency. Original Communication 2015 (doi: 10.1177/0148607114568121.

60. Lachmann R, Bevan MA, Kim S, Patel N, Hawrylowicz C, Vyakarnam A, et al. A comparative phase 1 clinical trial to identify anti-infective mechanisms of vitamin D in people with HIV infection. AIDS. 2015 Apr 13. [Epub ahead of print]

61. Holick MF, Binkley NC, BischoffFerrari HA, Gordon CM, Hanley DA, Heaney RP, et al. Evaluation, treatment, and prevention of vitamin D de- 
ficiency: an Endocrine Society clinical practice guideline. J Clin Endocrinol Metab. 2011;96(7):1911-1930.

62. Mosekilde L. Vitamin D and the elderly. Clin Endocrinol. 2005;62(3):265281.

63. Kendrick J, Targher G, Smits G, Chonchol M. 25-Hydroxyvitamin D deficiency is independently associated with cardiovascular disease in the third national and nutrition examination survey. Atherosclerosis. 2009;205(1):255260 .

64. Cigolini M, Jagulli MP, Miconi V, Galiotto M, Lombardi S, Targher G. Serum 25-hydroxyvitamin D3 concentrations and prevalence of cardiovascular disease among type 2 diabetic patients. Diabetes Care. 2006;29: 722-724.

65. Witham MD, Nadir MA, Struthers AD. Effect of vitamin D on blood pressure: a systematic review and meta-analysis. J Hypertens. 2009;27(10):1948-54.

66. Soysal P, Yay A, Işık AT. Does vitamin d deficiency increase orthostatic hypotension risk in the elderyl patients? Archives of Gerontology and Geriatrics. 2014;59:74-77.

67. Talaei A, Mohamadi M, Adgi Z. The effect of vitamin D on insulin resistance in patients with type 2 diabetes. Diabetol Metab Syndr. 2013;26;5(1):5-8.

68. Lapid MI, Cha SS, Takahashi PY. Vitamin D and depression in geriatric primary care patients. Clinical Interventions in Aging 2013;8: 509-514.

69. Gronli O, Kvamme JM, Jorde R, Wynn R. Vitamin D deficiency is common in psychogeriatric patients, independent of diagnosis. BMC Psychiatry. 2014;14:134.

70. Cavalcante IGM, Silva AS, Costa MJC, Persuhn DC, Issa CTMI, Freire TLL, Gonçalves MCR. Effect of vitamin D3 supplementation and influence of BsmI polymorphism of the VDR gene of the inflammatory profile and oxidative stress in elderyl women with vitamin $\mathrm{d}$ insufficiency vitamin D3 megadose reduces inflammatory markers. Experimental Gerontology. 2015;66:10-16.

71. Krishnan AV, Peehl DM, Feldman D. Inhibition of prostate cancer growth by vitamin D: regulationof targed gene expression. Journal of Cellular Biochemistry. 2003;88: 363-371.

72. Cavalcante I, Silva AS, Costa MJC, Persuhn DC, Issa C, Freire T, et al. Effect of vitamin D3 supplementation and influence of BsmI polymorphism of the VDR gene of the inflammatory profile and oxidative stress in elderly women with vitamin D insufficiency Vitamin D3 megadose reduces inflammatory markers.Experimental Gerontology 2015;66:10-16.

73. Prasad P, Kochhar A. Interplay of vitamin D and metabolic syndrome: A review Diabetes \& Metabolic Syndrome: Clinical Research \& Reviews xxx (2015) xxx-xxx. http://dx.doi.org/ 10.1016/j.dsx.2015.02.014

74. Kunutsor SK, Apekey TA, Steur M. Vitamin D and risk of future hypertension: meta-analysis of 283,537 participants. Eur J Epidemiol 2013;28:205-21.

75. Forman JP, Giovannucci E, Holmes MD. Plasma 25-hydroxyvitamin D levels and risk of incident hypertension. Hypertension 2007;49:1063-9.

76. Hypponen E, Boucher BJ, Berry DJ. 25Hydroxyvitamin D, IGF-1, and metabolic syndrome at 45 years of age: a crosssectional study in the 1958 British Birth Cohort. Diabetes 2008;57:298-305.

77. Forman JP, Scott JB, Drake BF, Suarez EG, Hayden DL, Bennett GG, et al. Effect of vitamin D supplementation on blood pressure in blacks. Hypertension 2013;61:779-85.

78. Vimaleswaran KS, Berry DJ, Lu C, Tikkanen E, Pilz S, Hiraki LT, et al. Causal relationship between obesity and vitamin D status: bi-directional Mendelian randomization analysis of multiple cohorts. PLoS Med 2013;10:e1001383.

79. Grineva EN, Karonova T, Micheeva E, Belyaeva O, Nikitina IL. Vitamin D deficiency is a risk factor for obesity and diabetes type 2 in women at late reproductive age. Aging 2013;5:575-81.

80. Guasch A, Bullo M, Rabassa A, Bonada A, Castillo D, Sabench F, et al. Plasma vitamin $\mathrm{D}$ and parathormone are associated with obesity and atherogenic dyslipidemia: a cross-sectional study. Cardiovasc Diabetol 2012;11: 149-60.
81. Salehpour A, Hosseinpanah F, Shidfar F, Vafa M, Razaghi M, Dehghani S, et al. A 12-week double-blind randomized clinical trial of vitamin D3 supplementation on body fat mass in healthy overweight and obese women. Nutr J 2012;11:78

82. Carrillo A, Flynn M, Pinkston C, Markofski M, Jiang Y, Donkin S, et al. Impact of vitamin D supplementation during a resistance training intervention on body composition, muscle function, and glucose tolerance in overweight and obese adults. Clin Nutr 2013;32:375-81

83. Mathieu C, Gysemans C, Giulietti A. Vitamin D and diabetes. Diabetologia 2005;48:1247-57.

84. Liu E, Meigs JB, Pittas AG. Plasma 25hydroxyvitamin $\mathrm{D}$ is associated with markers of the insulin resistant phenotype in nondiabetic adults. J Nutr 2009;139:329-34.

85. Pittas AG, Harris SS, Stark PC. The effects of calcium and vitamin D supplementation on blood glucose and markers of inflammation in nondiabetic adults. Diabetes Care 2007;30:980-6.

86. Harris SS, Pittas GA, Palermo JN. A randomized, placebo-controlled trial of vitamin D supplementation to improve glycaemia in overweight and obese African Americans. Diabetes Obes Metab 2012;14:789-94.

87. Jorde R, Grimnes G. Vitamin D and metabolic health with special reference to the effect of vitamin D on serum lipids. Prog Lipid Res 2011;50:303-12.

88. Jaimungal S, Wehmeier K, Mooradian AD, Haas MJ. The emerging evidence for vitamin D-mediated regulation of apolipoprotein AI synthesis. Nutr Res 2011;31:805-12.

89. Chai W, Cooney RV, Franke AA, Bostick RM. Effects of calcium and vitamin D supplementation on blood pressure and serum lipids and carotenoids: a randomized, double-blind, placebocontrolled, clinical trial. Ann Epidemiol 2013;23:564-70.

90. Pilz S, Tomaschitz A, Marz W, Drechsler C, Ritz E, Zittermann A, et al. Vitamin $\mathrm{D}$, cardiovascular disease and mortality. Clin Endocrinol (Oxf) 2011;75:575-84. 
